\title{
Pengaruh Perencanaan Serta Pelaksanaan dan Penatausahaan Terhadap Pertanggungjawaban Keuangan BUMDes
}

\author{
Teguh Widodo ${ }^{1}$, dan Suharyono ${ }^{2}$ \\ Prodi D4 Administrasi Bisnis Internasional, Politeknik Negeri Bengkalis ${ }^{1}$ \\ Prodi D4 Akuntansi Keuangan Publik, Politeknik Negeri Bengkalis ${ }^{2}$ \\ Email : teguhpolbeng@gmail.com, suharyono@ polbeng.ac.id ${ }^{2}$
}

\begin{abstract}
This study aims to determine the effect of planning (X1), implementation and administration (X2) variables on accountability $(Y)$. The object of this research is BUMDes in Bengkalis Regency, Riau. The method of determining the sample in this study using purposive sampling with a total sample of 32 BUMDes. The results of the study prove that the planning (X1), implementation and administration (X2) variables for accountability (Y) are partially or simultaneously. This proves that in BUMDes management, planning and implementation as well as administration in accordance with regulations and standard operating procedures will have an impact on optimal BUMDes management accountability.
\end{abstract}

Keywords: Planning, Implementation, Administration, Accountability, BUMDes.

\section{Pendahuluan}

Tingkat pertumbuhan aspek ekonomi yang tinggi selalu dihadapkan dengan permasalahan pendapatan masyarakat yang belum merata. Biasaya pertumbuhan ekonomi yang meningkat hanyalah menjadi keuntungan bagi sekelompok kecil masyarakat yaitu masyarakat perkotaan, sedangkan kehidupan ekonomi masyarakat desa hanya mendapat porsi kecil. Kesenjangan akses, pembangunan dan infrastruktur antara kota dan desa harus dibenahi. Kesejahteraan masyarakat desa lebih rendah dibandingkan kesejahteraan penduduk kota. Hal ini dapat dilihat dari tingkat kemiskinan di desa dua kali lipat dibandingkan persentasi penduduk miskin di kota.

Bidang perekonomian menjadi hal urgen yang harus dikembangkan di seluruh desa di Indonesia. Pemerintah melalui Kementerian Desa, PDT dan Transmigrasi maupun kementerian lainnya sudah merealisasikan berbagai kebijakan dalam mendukung peningkatan perekonomian di desa. Mulai dari dana 
desa, bantuan UMKM dimasa pandemi akibat terdampak Covid-19, kartu prakerja, dan pendirian BUMDes. Namun kebijakan-kebijakan tersebut membutuhkan pengawasan dan evaluasi oleh lembaga berwenang, agar tujuan kebijakan baik output maupun outcome bisa tercapai dengan optimal. Dibutuhkan dobrakan dalam meningkatkan elemen kreatif dan inovatif dari masyarakat desa agar mampu mengembangkan potensi-potensi desa yang unggul dan bernilai ekonomi. Jika BUMDes di desa yang salah urus akan berdampak pada kegagalan kemandirian desa sehingga tetap bergantung dari bantuan pemerintah (Alfianto, 2019).

Kekurangan yang dimiliki masyarakat desa adalah sulitnya akses untuk melakukan hilirisasi produk dan sulitnya memasarkan hasil-hasil perkebunan, pertanian maupun perikanan. Untuk itu, desa harus mampu menggali potensi desa guna peningkatan kesejahteraan masyarakatnya. Melalui BUMDes harapan untuk mensejahterakan masyarakat diharapkan dapat terwujud, dengan membantu memberikan solusi atas permasalahan masyarakat (Suwarno, 2020). BUMDes dapat memasarkan sumber daya dan potensi desa ke pasar yang lebih luas.

Menurut Permendesa Nomor 4 tahun 2015 tentang Pendirian, Pengurusan dan Pengelolaan, dan Pembubaran Badan Usaha Milik Desa, yang menjadi pendoman bagi daerah dan desa dalam pembentukan dan pengelolaan BUMDes. BUMDes sebagi badan usaha, seluruh atau sebagian besar modalnya dimiliki oleh desa melalui penyertaan secara langsung yang berasal dari kekanyaaan desa.

Didirikannya BUMDes diseluruh desa di Indonesia merupakan strategi dalam mempercepat pembangunan perekonomian di desa. Konsep pendirian BUMDes menggunakan konsep pemberdayaan masyarakat untuk elemen-elemen keberdayaan masyarakat demi peningkatan kualitas hidup lapisann masyarakat yang belum bisa mandiri mengandalkan kemampuannya sehingga BUMDes menjadi solusi bagi masyarakat untuk keluar dari perangkap kemiskinan dan ketertinggalan. BUMDes menjadi solusi dan meningkatkan kemampuan dan kemandirian warga desa. BUMDes menjadi pelopor dalam mengelola potensipotensi sumber daya dan potensi pembangunan yang dilaksanakan dengan dengan 
melibatkan partisipasi warga.

BUMDes sangat diharapkan warga untuk dapat mewujudkan cita-cita demokrasi sosial di desa. Demokrasi sosial akan tercermin dari peningkatan kualitas dan kapasitas warga tentang pengelolaan sumber daya potensi desa secara berkelanjutan. Selain itu, masyarakat desa ikut berperan serta dalam mendukung keberadaan BUMDes agar pengelolaan BUMDes dapat dilakukan secara optimal.

Pemerintah desa sebagai pioneer pembangunan desa diharapkan dapat kreatif dan inovatif dalam membangun perekonomian desa. Melalui kepemilikan BUMDes dan pengelolaan BUMDes yang baik, dapat membangun desa terutama dalam menciptakan lapangan pekerjaan, meningkatkan kualitas dan kuantitas produksi barang dan jasa, meningkatkan omzet perdagangan atau perputaran dana di desa memberikan pelayanan yang optimal bagi pelanggan. BUMDes didirikan untuk membawa perubahan desa kearah yang lebih baik dengan tujuan sebagai agen perubahan pembangunan desa dan sebagai penggebrak dalam menciptakan sektor ekonomi di pedesaan yang efisien dan ekonomis.

Mengelola BUMDes mengacu di Permendes Nomor 4 Tahun 2015 tentang mendirikan, mengelola, mengurus, dan membubatkan BUMDes. Mengelola keuangan BUMDes berpatokan pada pengurusan keuangan yang tahapannya dimulai dengan rencana anggaran, merealisasikan rencana, penatausahaan keuangan, menyusun laporan keuangan, dan akuntabilitas pengelolaan aset BUMDes.

Perencanaan merupakan rencana sumber dana masuk dan dana keluar dalam satu tahun anggaran (Suharyono, 2020). Pelaksanaan merupakan realisasi penerimaan dan pengeluaran. Penatausahaan merupakan pelaksana fungsi kebendaharaan. Pelaporan merupakan proses penyusunan laporan keuangan. Pertanggungjawaban merupakan laporan pertanggungjawaban direktur BUMDes atas pengelolaan usaha.

Pengurus BUMDes sebagai pengelola operasional memiliki kewajiban untuk memajukan dan mendevelop BUMDes menjadi badan usaha yang mampu 
memberikan pelayanan prima khususnya memberikan pelayanan untuk memenuhi kebutuhan perekonomian masyarakat desa. Selain itu, BUMDes juga dapat memberikan pelayanan umum masyarakat, melakukan inventarisasikan potensi desa dengan menggali potensi-potensi yang bernilai ekonomi dan memanfaatkan potensi-potensi unggulan desa demi peningkatan sumber PAD desa, dan menjalin kerjasama yang optimal dengan Badan Usaha Milik Desa di desa-desa lainnya demi membawa perubahan dan kemajuan desa.

Laporan keuangan merupakan dokumen lengkap yang berisikan seluruh informasi keuangan atas pencatatan transaksi keuangan yang dicatat berdasarkan bukti-bukti yang dapat dipercaya yang dapat memberikan informasi akurat dan tepat tentang kinerja BUMDes dalam satu periode pelaporan (Peraturan Pemerintah Nomor 71, 2010). Laporan keuangan yang telah disusun dan berisikan informasi keuangan sangat berguna untuk memilih alternatif keputusan agar keputusan yang diambil tepat sasaran, serta sebagai perwujudan akuntabilitas BUMDes atas pengelolaan aset-aset BUMDes yang diamanahkan masyarakat kepada pengurus BUMDes. Penelitian ini memiliki tujuan untuk mendapatkan bukti dan gambaran tentang pengelolaan keuangan BUMDes di Kabupaten Bengkalis.

\section{Tinjauan Pustaka}

\subsection{Badan Usaha Milik Desa}

BUMDes di Kabupaten Bengkalis dapat mengelola bisnis sosial (social business) dalam skala yang sedrhana guna memberikan pelayanan (serving) kepada masyarakat desa dengan target untuk memperoleh keuntungan finansial (earning). Pendirian unit usaha dapat dilakukan BUMDes untuk memudahkan fokus dan pemisahan tugas dan tanggungjawab yang baik. Manahemen BUMDes dapat memanfaatkan sumber daya yang dimiliki desa atau sumber daya lokal dan teknologi tepat guna sebagai unit bisnisnya. Bebarapa contoh unit-unit usaha BUMdes meliputi:

1. Air minum desa di Desa Muara Dua,

2. Usaha listrik desa, 
3. Lumbung pangan di Desa Bukit Batu, Temiang, Api-Api, Mentayan, Selat Baru, Berancah, Pematang Duku, Langkat, Sepotong, dan Tanjung Damai, dan 4. Sumber daya lokal dan teknologi tepat guna lainnya.

Dalam pengelolaan BUMDes, pengelola BUMDes akan diminta pertanggungjawabannya atas pengelolaan sumber daya yang dimiliki BUMDes. Pertanggungjawaban dalam pelaksanaan pengeloaan BUMDes prosedurnya adalah pelaksana operasional BUMDes wajib melaporkan pertanggungjawaban pelaksanaan BUMDes kepada komisaris selaku penasihat yang secara ex-officio dijabat oleh kepala desa. Sedangkan kepalaa desa harus mempertanggungjawabkan kepada BPD yang melakukan pengawasan terhadap kinerja Pemerintah Desa dalam membina pengelolaan BUMDes. Selain itu, Pemerintah Desa juga harus mempertanggungjawabkan tugas-tugas terkait pembinaan terhadap BUMDes kepada BPD yang dilaksanakan melalui forum Musyawarah Desa.

\subsection{Peneliti Terdahulu}

BUMDes disebut juga perusahaan milik desa yang didirikan dan diurus oleh pemerintah desa demi terciptanya peningkatan ekonomi bagi masyarakat desa berbasis potensi desa. BUMDes mendapatkan permodalan dari aset pemerintah desa berupa setoran modal dari pemerintah desa dan menjadi aset yang terpisah dari aset pemerintah desa. Menurut Mahmudah (2018) yang melakukan penelitian di Desa Sungonlegowo, menyatakan bahwa BUMDes di Desa Sungonlegowo, konisinya hari ini masih dalam tahap berkembang dan 4 unit bisnis, yaitu Hippam, Pelabuhan, PPOB, Tabungan dan Pinjaman. Secara bisnis keempat bisnis telah dikelola oleh tim yang profesional dan telah mendapatkan laba dari hasil pengelolaan tersebut. Disisi lain, laporan keuangan BUMDes disusun secara sederhana yang terus disempurnakan agar wajar dan memenuhi standar keuangan yang berlaku umum.

Penelitian yang berkaitan dengan akuntabilitas tidak pernah ada ujungnya dibidang akuntansi. Penelitian Onsardi (2020) menunjukkan bahwa transparansi dan pertanggungjawab dana desa di Desa Taba Padang Rejang sudah sejalan prespektif islam dan mengikuti kaedah yang ditetapkan dalam peraturan yang 
berlaku serta mengikuti aspek syariah. Penyusunan rencana telah melibatkan masyarakat melalui musyawarah desa dan diputuskan hal-hal yang sesuai dengan kebutuhan desa. Hasilnya pengelolaan Dana Desa telah memenuhi unsur transparan dan adanya partisipasi warga. Namun disisi lain, terjadi keterlambatan pelaporan terkait pengelolaan Dana Desa di desa Taba Padang Rejang.

Penelitian Wahyudi (2018) bertujuan mengukur pengaruh implementasi tanggung jawab renteng dalam menghadapi resiko non performing loan pada BUMDES Cipta Karya yang bergerak dibidang pembiayaan. Metode penelitiannya menggunakan metode investigasi. Hasil yang diperoleh dalam penelitian ini adalah adanya hubungan setara antara kinerja manajerial, kelompok, maupun kinerja BUMDes. Kesetaraan tersebut telah mendukung perkembangan serta kemajuan BUMDes. Namun, untuk variabel kinerja keuangan system tanggung renteng belum mampu menunjukkan perubahan resiko kredit.

Penelitian Dwidiyantini (2017) dilakukan untuk mendapatakan bukti tentang pengelolaan dan akuntabilitas keuangan BUMDes Tugu Sari Pajahan. Hasil Penelitian menunjukan (1) laporan keuangan telah disusun oleh manajemen BUMDes dan manghasilakn laporan laba rugi dan laporan posisi keuangan dengan format yang simpel; (2) kendala dalam penyusunan laporan adalah sumber daya manusia yang belum mampu mengoperasikan aplikasi computer, sehingga masih dilakukan secara manual di excel; dan (3) terdapat penyesuaian pada laporan keuangan yang berdampak pada perubahan saldo di beberapa akun laporan keuangan.

Ramadhani (2016) menganalisis Badan Usaha Milik Desa (BUMDes) di Kabupaten Rokan Hulu dari aspek keuangan dengan menilai kinerja keuangan BUMDes berbasis rasio. Metode yang digunakan dalam menganalisi kinerja keuangan yaitu metode perbandingan. Kinerja keuangan BUMDes di Kabupaten Rokan Hulu menggambarkan bahwa rasio lancarnya sebesar 277\% (sangat baik), Debt to Asset Ratio (DAR) sebesar 42\% (baik), Return On Asset (ROA) sebesar 8\% (baik), sedangkan Total Asset Tun Over (TATO) sebesar 0,23 kali (tidak baik).

Irawati (2018) melakukan penelitian tentang manajemen keuangan dan 
pelaporan aset desa, untuk menilai aspek transparansi BUMDes dalam melaporkan aset. Metode pengumpulan data dilakukan melalui wawancara. Hasilnya adalah bentuk transparansi tercermin dari penyusunan laporan keuangan BUMDes yang dilengkapi dengan rincian daftar aset yang dikelola oleh BUMDes. Hasil penelitian Ihsan (2018) padaBUMDes Gerbang Lentera menunjukkan bahwa manajemen telah dilaksanakan dengan baik dan telah menjadi percontohan bagi BUMDes di desa lain di Semarang. Hasil penelitian telah diperkuat buktibukti tentang kondisi terkini unit-unit usaha yang dikelola secara efektif. BUMDes memiliki keunggulan sumber daya, partisipasi aktif dari masyarakat, pemberdayaan masyarakat, pemerintah yang all out dalam mendukung usaha dan terjalinnya kerjasama dengan berbagai pihak.

Nilawati (2018) melakukan penelitian pada BUMDesa Hanyukupi. Hasilnya manajemen BUMDes telah menempuh dan menjalankan perencanaan dengan menyusun rencana kerja tahunan BUMDes. Manajemen BUMDes juga telah membentuk Anggaran Dasar (AD) dan Anggaran Rumah Tangga (ART). Pembagian tugas dan wewenang sesuai dengan struktur BUMDes. Rekruitmen secara profesional dan menerapkan pengembangan karir. Manajemen kontrol telah dijalan untuk meraih tujuan secara efektif dan efisien.

\subsection{Perencanaan}

Perencanaan merupakan dokumen awal yang harus disusun dan disiapkan oleh pengurus BUMDes. Dokumen perencanaan setidaknya memuat analisis kelayakan investasi yang memuat perhitungan net present value, payback periode, profitability index, dan internal rate of return. Selain itu perencanaan juga menyangkut penyusunan anggaran keuangan yang meliputi capital expenditure, operational expenditure, analisa break event point, proyeksi laba rugi, dan sumber dana (Suharyono, 2019). Sumber dana bisa diperoleh melalui investor, kreditor ataupun dana sendiri. Perencanaan mesti diarahkan semaksimal mungkin supaya bias menggambarkan latar belakang diambilnya keputusan saat menetapkan arah kebijakan. Selain itu perencanaan harus mampu menentukan skala prioritas dan menentukan alokasi dan distribusi sumber daya. 
Berdasarkan PP No 58 tahun 2005 prinsip yang menjadi pedoman dalam penyusunan anggaran yaitu perencanaan total pendapatan yang diperkirakan harus dapat diukur secara rasional, sedangkan belanja yang dianggarkan merupakan harga batas tertinggi. Selain itu, anggaran untuk pengeluaran mesti dapat dipastikan tersediannya penerimaan dalam jumlah yang cukup.

Agar tingkat efisiensi dan efektifitas anggaran mampu dikendalikan, maka anggaran harus memiliki tujuan dan sasaran yang jelas, hasil, manfaat, serta sesuai dengan indikator kinerja yang ditetapkan. Prioritas kegiatan dan penghitungan beban kerja juga harus ditetapkan, sedangkan harga satuan harus ditetapkan secara rasional (Hermanto, 2020).

\subsection{Pelaksanaan dan Penatausahaan}

Dalam aspek pelaksanaan dan penatausahaan, dana yang dianggarkan wajib dikelola secara efektif, efisien dan ekonomis. Pelaksanaan harus berpedoman pada peraturan dan standar operasional prosedur yang telah disahkan. Dengan pelaksanaan dan penatausahaan yang dilaksanakan secara baik dan sesuai prosedur, maka tujuan BUMDes akan dapat dicapai dengan baik (Suharyono, 2020).

\subsection{Pertanggungjawaban}

Pertanggungjawaban dalam bidang pelaporan dan akuntansi bertujuan untuk mewujudkan transparansi dan akuntabilitas. Pertanggungjawaban merupakan kewajiban bagi pengurus BUMDes untuk mengakuntabilitaskan pengendalian sumber-sumber daya yang dimiliki BUMDes dan mempertanggungjawabkan rencana dan realisasi atas pelaksanaan kebijakan yang telah diambil dalam mengelola BUMDes. Pertanggungjawaban pengurus BUMDes disusun dalam bentuk laporan yang lengkap baik laporan keuangan maupun laporan kinerja.

Pada hakikatnya pertanggungjawaban merupakan gambaran atas hasilhasil kegiatan yang telah dilaksanakan. Hasil kegiatan yang tertuang dalam laporan pertanggungajawaban dalam menggambarkan alaisis situasi pengelolaan 
BUMDes, yang sesuai dengan prosedur yang telah ditetapkan. Selain itu, laporan pertanggungjawaban membuat output atau capaian kegaitan. Output yang dicapai hendaknya sesuai dengan rencana awal yang ditetapkan.

\section{Metode Penelitian}

\subsection{Jenis Penelitian}

Penelitian ini dilakukan dengan pendekatan kuantitatif. Metode kuantitatif akan membutuhkan data-data angka yang dikumpulkan melalui kuesioner penelitian. Metode kuantitatif menitikberatkan pada kegiatan penelitian yang pengukuran dilakukan secara objektif untuk mendapatkan hasil yang objektif menggunakan analisis statistik.

\subsection{Lokasi Penelitian}

Penelitian ini dilaksanakan di Kabupaten Bengkalis, Provinsi Riau. Waktu Penelitian Penelitian ini dilaksanakan selama empat bulan, yang dimulai sejak Juli sampai dengan November 2020. Kegiatan yang dilaksanakan meliputi pengumpulan dan analisis data.

\subsection{Data Penelitian}

Penelitian untuk menganalisis manajemen keuangan di BUMDes menggunakan data primer. Data primer diperoleh melalui penyebaran kuesioner ke BUMDes yang telah terpilih sebagai sampel. Penyebaran kuesioner dilakukan dengan menggunakan kuesioner daring.

\subsection{Populasi dan sampel}

Populasi adalah wilayah generalisasi yang terdiri atas obyek atau subyek yang mempunyai kualitas atau karakteristik tertentu yang ditetapkan oleh peneliti untuk dipelajari dan kemudian ditarik kesimpulannya (Sugiyono, 2014). Populasi yang akan digunakan dalam penelitian ini adalah BUMDes yang ada di Kabupaten Bengkalis yaitu berjumlah 136. Metode penentuan sampel pada penelitian ini menggunakan purposive sampling dengan total sampel sebanyak 32 BUMDes. BUMDes yang dijadikan sampel mewakili seluruh kecamatan yang ada di Kabupaten Bengkalis, Riau. 


\subsection{Variabel Penelitian}

Dalam penelitian ini, variabel terikat atau varibel dependen adalah pertanggungjawaban $(\mathrm{Y})$, sedangkan perencanaan anggaran $(\mathrm{X} 1)$ dan pelaksanaan dan penatausahaan (X2) merupakan variabel bebas atau variabel independen.

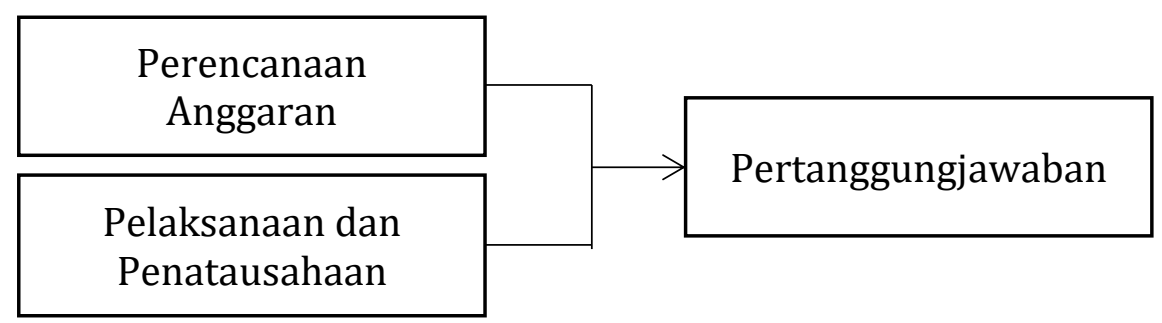

\section{Gambar 1. Variabel Penelitian}

\subsection{Teknik Analisis Data}

Penelitian kuantitatif ini, pengolahan data dilakukan setelah semua data terkumpul dan disusun dalam sebuah tabulasi data. Data yang ditabulasi berasal dari kuesioner yang telah diperoleh. Teknik analisis data dalam penelitian ini menggunakan analisis regresi. Alat uji yang digunakan yaitu uji t untuk mengukur pengaruh antar variabel secara parsial, sedangkan untuk mengukur pengaruh antar variabel secara simultan alat uji yang digunakan adalah uji F.

\section{Hasil Dan Pembahasan}

\subsection{Uji Deskriptif}

Hasil uji deskriptif atas pengolahan data penelitian menggunakan SPSS yang disajikan dalam tabel 2 dapat diketahui bahwa:

1. Variabel perencanaan anggaran (X1) nilai minimum adalah 45 sedangkan nilai maksimum variabel perencanaan sebesar 69, dengan 15 item pernyataan. Ratarata nilai atau mean sebesar 61,4 ;

2. Variabel pelaksanaan dan penatausahaan (X2) nilai minimum adalah 42 sedangkan nilai maksimum 71, dan mean sebesar 52,5;

3. Variabel pertanggungjawaban (Y) nilai minimumnya adalah 40 dan nilai maksimumnya sebesar 66. Dengan rata-rata sebesar 46,7. 
Tabel 1. Output SPSS untuk Uji Deskriptif

\begin{tabular}{|c|c|c|c|c|c|}
\hline No & Variabel & $\mathrm{n}$ & Min & Maks & Mean \\
\hline 1 & Perencanaan anggaran & 32 & 45 & 69 & 61,4 \\
\hline 2 & $\begin{array}{l}\text { Pelaksanaan dan } \\
\text { penatausahaan }\end{array}$ & 32 & 42 & 71 & 52,5 \\
\hline 3 & Pertanggungjawaban & 32 & 40 & 66 & 46,7 \\
\hline
\end{tabular}

\subsection{Uji Asumsi Klasik}

Uji normalitas dilaksanakan agar data penelitian yang telah dikumpul dapat diolah dan dianalisa menggunakan statistic parametric. Jika data tidak normal maka akan berdampak pada perubahan alat uji yang digunakan. Uji normalitas bertujuan untuk mengukur sampel yang digunakan dalam penelitian apakah berdistribusi normal atau sebalikanya. Alat uji normalitas yang dipakai adalah uji One-Simple Kolgomorov Smirnov. Hasil uji normalitas yang diiperoleh dari output SPSS sebesar 0,200. Ini membuktikan bahwa data penelitian ini berdistribusi normal dan dapat menggunakan uji statistik parametrik dalam menguji hipotesis penelitian.

Selanjutnya adalah uji multikolinieritas. Uji ini dilakukan untuk menilai ada tidaknya keterkaitan antar variabel bebas, yaitu hubungan antara variabel perencanaan anggaran dengan variabel pelaksanaan dan penatausahaan di BUMDes Kabupaten Bengkalis. Hasil output SPSS menunjukkan bahwa nilai VIF sebesar 1,171. Keputusan dalam menentukan Vaiance Inflaion Factor (VIF) adalah apabila nilai VIF diatas 10 atau tolerance lebih kecil dari 0,10, maka keputusannya adalah terdapat multikolinearitas. Sedangkan jika nilai VIF lebih kecil dari 10 atau tolerance melebihi 0,10 maka dinyatakan bebas multikolinearitas. Dengan demikian dapat dibuktikan bahwa data penelitian ini bebas multikolinearitas.

Uji asumsi klasik yang terakhir adalah uji heteroskedastisitas. Uji heteroskedastisitas adalah uji yang dilakukan untuk meihat apakah model regresi terjadi ketidaksamaan varians dari residual satu pengamatan ke pengamatan yang lain. Apabila varians residual tetap, maka dapat dikatakan homokedastisitas, sedangkan jika varian residual berbada, itulah yang disebut heteroskedastisitas. 
Untuk mendeteksinya digunakan Uji Glejser. Jika sig lebih besar dari 5\% maka bebas heteroskedastisitas, sebaliknya apabila sig lebih kecil dari 5\% maka terdapat heteroskedastisitas. Berdasarkan output SPSS nilai sig untuk uji heteroskedastisitas sebesar 0,87. Dengan demikian data penelitian ini bebas heteroskedastisitas.

\subsection{Uji Hipotesis}

Dilakukannya penelitian pada BUMDes di Kabupaten Bengkalis Riau ini untuk membuktikan pengaruh perencanaan anggaran, pelaksanaan dan penatausahaan terhadap pertanggungajawaban dalam pengelolaan BUMDes. Hasil penelitian membuktikan bahwa berdasarkan output pengolahan data menggunakan SPSS 22 diperoleh nilai t hitung lebih besar dari nilai table. Pengolahan data melalui uji parsial ( $t$ test) yang dilaksanakan telah menghasilkan output spss dalam penelitian ini dan menunjukkan hasil, yaitu:

1. Pengujian hipotesis pertama untuk membuktikan pengaruh perencanaan terhadap pertanggungjawaban menunjukkan bahwa output uji t yang disajikan pada tabel 1, didapatkan nilai t hitung sebesar 2,628 lebih besar dari nilai t table dengan nilai 2,036. Didukung dengan nilai signifikan variabel X1 (perencanaan) sebesar 0,000 < dari 0,05 dan diputuskan bahwa H1 diterima. Output SPSS juga menunjukkan bahwa nilai $\mathrm{t}$ hitung adalah positif. Ini menandakan bahwa antara variabel X1 (perencanaan) dan variable $\mathrm{Y}$ (pertanggungjawaban) menunjukkan hubungan yang selaras. Ini menunjukkan bahwa terdapat pengaruh positif antar variabel. Hal tersebut menunjukkan bahwa variabel perencanaan keuangan berpengaruh positif dan signifikan terhadap pertanggungjawaban.

2. Pengujian hipotesis kedua untuk membuktikan pengaruh pelaksanaan dan penatausahaan terhadap pertanggungjawaban menunjukkan bahwa output uji $t$ yang disajikan pada tabel 1, didapatkan nilai t hitung sebesar 3,001 lebih besar dari nilai t tabel dengan nilai 2,036. Didukung dengan nilai signifikan variabel $\mathrm{X} 2$ (pelaksanaan dan penatausahaan) sebesar 0,000 < dari 0,05 dan diputuskan bahwa H1 diterima. Output SPSS juga menunjukkan bahwa nilai t hitung 
adalah positif. Ini menandakan bahwa antara variabel X2 (pelaksanaan dan penatausahaan) dan variable $\mathrm{Y}$ (pertanggungjawaban) menunjukkan hubungan yang selaras. Ini menunjukkan bahwa terdapat pengaruh positif antar variabel. Hal tersebut menunjukkan bahwa variabel pelaksanaan dan penatausahaan berpengaruh positif dan signifikan terhadap pertanggungjawaban.

Tabel 1. Output SPSS untuk Uji t

\begin{tabular}{llcccl}
\hline No & \multicolumn{1}{c}{ Variabel } & $\begin{array}{l}\text { Nilai t } \\
\text { Hitung }\end{array}$ & $\begin{array}{l}\text { Nilai t } \\
\text { Tabel }\end{array}$ & Sig & Keputusan \\
\hline 1 & $\begin{array}{l}\text { Perencanaan } \\
\text { anggaran }\end{array}$ & 2,628 & 2,036 & 0,000 & $\begin{array}{l}\text { Ada } \\
\text { pengaruH } \\
\text { Ada } \\
\text { pengaruh }\end{array}$ \\
\hline
\end{tabular}

Secara simultan hasil penelitian dapat disimpulkan bahwa variabel perencanaan anggaran serta variabel pelaksanaan dan penatausahaan juga memiliki pengaruh terhadap pertanggungjawaban. Hasil ini didasari pada output SPSS untuk uji F dengan hasil F hitung sebesar 9,205, sedangkan F tabel sebesar 3.290. Ini membuktikan bahwa dalam pengelolaan BUMDes, perencanaan dan pelaksanaan serta penatausahaan yang sesuai peraturan dan standar operasional prosedur akan berdampak pada pertanggungjawaban pengelolaan BUMDes yang optimal.

Tabel 2. Output SPSS untuk Uji F

\begin{tabular}{lllll}
\hline No & \multicolumn{1}{c}{ Variabel } & $\begin{array}{c}\text { Nilai F } \\
\text { Hitung }\end{array}$ & $\begin{array}{c}\text { Nilai F } \\
\text { Table }\end{array}$ & Keputusan \\
\hline 1 & $\begin{array}{l}\text { Perencanaan anggaran, } \\
\text { pelaksanaan dan penatausahaan }\end{array}$ & 9,205 & 3,290 & $\begin{array}{l}\text { Ada } \\
\text { pengaruh }\end{array}$ \\
\hline
\end{tabular}

BUMDes diharapkan dapat melakukan pengelolaan keuangan sesuai dengan tahapan yang telah ditetapkan yaitu mulai perencanaan, pelaksanaan, penatausahaan, pelaporan, hingga pertanggungjawaban. Dengan mengikuti tahapan-tahapan tersebut maka pengelolaan keuangan dapat dilakukan secara transparan dan akuntabel. Ini akan berdampak kepada masyarakat desa yang 
memberikan kepercayaan kepada BUMDes untuk meningkatkan kesejahteraan masyarakat. Keberhasilan BUMDes sangat bergantung dari dukungan dan kepercayaan masyarakat desa.

Pengelolaan keuangan BUMDes yang akuntabilitas dapat terwujud jika pengelola operasional BUMDes dan Pemerintah Desa memenuhi kewajibannya menyampaikan amanah atau pertanggungjawaban atas pengelolaan sumber daya ekonomi desa kepada masyarakat selaku pihak yang harus diberdayakan atau BPD selaku pengawas Pemerintah Desa yang berhak menerima pertanggungjawaban. Pertanggungjawaban yang dapat diterima dengan baik tentunya adala pertanggungjawaban atas manajemen keuangan yang optimal yang seluruh tahap dilaksanakan dengan baik mulai dari perencaraan hingga pelaporan pertanggungjawaban. Untuk itu, seluruh BUMDes di Kabupaten Bengkalis haruslah memahami bahwa proses yang baik akan menghasilkan laporan pertanggungjawaban yang baik.

Pengelolaan keuangan BUMDes yang baik, juga harus menerapkan prinsip keterbukaan atau transparansi. Manajemen BUMDes yang transparan memungkinkan masyarakat untuk memahami dan mendapatkan akses informasi yang utuh, lengkap dan dapat dipercaya tentang keberlangsungan usaha BUMDes. Dengan menerapkan prinsip transparansi dalam pengelolaan BUMDes, telah menjamin akses atau kebebasan bagi setiap orang untuk memperoleh informasi tentang kinerja BUMDes.

Hasil penelitian ini sejalan dengan penelitian Ihsan (2018) yang mengatakan bahwa akuntabilitas yang optimal tercermin dari pengelolaan sumber daya yang tersedia dengan transparan, partisipasi masyarakat, dukungan dari pihak-pihak yang berkepentingan dan adanya kerjasama yang menguntungkan dengan para pemasok. Selain itu hasil penelitian ini juga mendukung penelitian Rofidah (2020), bahwa BUMDes telah menerapkan PP 58 tahun 2005 baik dalam perencanaan, pelaksanaan, penatausahaan, pelaporan dan pertanggungjawaban.

\section{Kesimpulan}

Penelitian ini bertujuan untuk mengetahui pengaruh antara variabel 
perencanaan (X1), pelaksanaan dan penatausaahaan (X2) terhadap pertanggungjawaban (Y). Objek penelitian ini adalah BUMDes di Kabupaten Bengkalis, Riau. Metode penentuan sampel pada penelitian ini menggunakan purposive sampling dengan total sampel sebanyak 32 BUMDes. Hasil penelitian membuktikan bahwa variabel perencanaan (X1), pelaksanaan dan penatausaahaan (X2) terhadap pertanggungjawaban (Y) baik secara parsial maupun secara simultan. Ini membuktikan bahwa dalam pengelolaan BUMDes, perencanaan dan pelaksanaan serta penatausahaan haruslah mengikuti peraturan dan standar operasional prosedur yang berlaku. Ini akan berdampak pada pertanggungjawaban pengelolaan BUMDes yang optimal.

\section{DAFTAR PUSTAKA}

Alfianto, M. (2019). Kinerja Keuangan Bumdes Di Kecamatan Salem (Doctoral dissertation, Universitas Peradaban).

Dwidiyantini, K. A., Sulindawati, N. L. G. E., \& Edy Sujana, S. E. (2017). Penyusunan Laporan Keuangan Manufaktur pada badan Usaha Milik Desa (BUMDES) Tugu Sari Pajahan Kecamatan Pupuan Kabupaten Tabanan. JIMAT (Jurnal Ilmiah Mahasiswa Akuntansi) Undiksha, 7(1).

Hermanto, C. B. (2020). Pengaruh Perencanaan, Pelaksanaan, Monitoring Dan Evaluasi, Dan Pertanggungjawaban Anggaran Dengan Implementasi Anggaran Berbasis Kinerja Terhadap Akuntabilitas Kinerja Instansi Pemerintah (Survey di Kementerian Pemberdayaan Perempuan dan Perlindungan. Jurnal Akrab Juara, 5(3), 40-56.

Ihsan, A. N., \& Setiyono, B. (2018). Analisis Pengelolaan Badan Usaha Milik Desa (BUMDes) Gerbang Lentera Sebagai Penggerak Desa Wisata Lerep. Journal of Politic and Government Studies, 7(04), 221-230.

Irawati, D., \& Martanti, D. E. (2018). Transparansi Pengelolaan Laporan Keuangan BUMDes Terhadap Pelaporan Aset Desa (Studi Fenomenologi Pada BUMDes Desa Karangbendo Kec Ponggok Kab Blitar). UNEJ eProceeding, 41-51.

Mahmudah, S. (2018). Akuntabilitas Laporan Keuangan Badan Usaha Milik Desa (Studi Kasus: BUMDes Desa Sungon Legowo Bungah Gresik). Ecopreneur. 12: Journal Economic and Business, 1(2), 32-36.

Nilawati, E. (2018). Analisis Manajemen Badan Usaha Milik Desa (BUMDESA)“Hanyukupi” Desa Ponjong Kecamatan Ponjong Kabupaten Gunungkidul. Jurnal Wacana Kinerja, 21(1), 49-72.

Onsardi, O., Marini, M., \& Selvia, E. (2020). Akuntabilitas Pengelolaan Dana Desa Dalam Perspektif Islam (Studi Kasus Di Desa Taba Padang Rejang Kecamatan Huku Palik Kabupaten Bengkulu Utara). Bilancia: Jurnal Ilmiah Akuntansi, 4(3), 248-261. 
Ramadhani, A. (2016). Analisis Perbandingan Kinerja Keuangan Badan Usaha Milik Desa (Bumdes) di Kabupaten Rokan Hulu. Cano Ekonomos, 5(1), 110 .

Republik Indonesia, Peraturan Pemerintah No. 58 Tahun 2005 Tentang Pengelolaan Keuangan Daerah.

Republik Indonesia, Permendesa Nomor 4 tahun 2015 tentang Pendirian, Pengurusan dan Pengelolaan, dan Pembubaran Badan Usaha Milik Desa

Republik Indonesia, Peraturan Pemerintah Nomor 71 Tahun 2010 tentang Standar Akuntansi Pemerintahan.

Rofidah, N., \& Rochayatun, S. (2020). Implementasi Pengelolaan Keuangan Badan Usaha Milik Desa (Studi Desa Gondowangi Kecamatan Wagir Kabupaten Malang). EL MUHASABA: Jurnal Akuntansi (e-journal), 11(1), 60-70.

Sugiyono. (2014). Metode penelitian kuantitatif, kualitatif dan $r \& d$. Bandung:Alfabeta.

Suharyono, S. (2020). Evaluasi Penggunaan Dana Desa dan Alokasi Dana Desa. Jurnal Ilmiah Universitas Batanghari Jambi, 20(2), 648-651.

Suharyono, S. (2019). The Effect Of Accountability, Transparency, And Supervision On Budget Performance By Using The Concept Of Value For Money In Regional Business Enterprises (BUMD) Of Riau Province. International Journal of Public Finance, 4(2), 236-249.

Suharyono, S. (2020). Analisis Kinerja Pemerintah Provinsi Di Indonesia. Jurnal Neraca: Jurnal Pendidikan dan Ilmu Ekonomi Akuntansi, 4(1), 11-25.

Suwarno, S. (2019). Pengelolaan Keuangan Desa: Perencanaan sampai dengan Pertanggungjawaban pada Desa di Kecamatan Cilongok Banyumas. JRAP (Jurnal Riset Akuntansi dan Perpajakan), 6(01).

Wahyudi, A., \& Rustantia, F. (2018). Sistem Tanggung Renteng Sebagai Strategi Pembiayaan Dalam Meningkatkan Kinerja Bumdes Yang Bankable Pada Masyarakat Desa (Studi Fenomenologi Pada Laporan Keuangan BUMDES Cipta Karya Desa Ngeni Kabupaten Blitar Per Agustus 2016-Agustus 2017). UNEJ e-Proceeding, 35-40.

Yustisia, T. V. (2016). Pedoman Resmi Petunjuk Pelaksanaan Dana Desa: Himpunan Peraturan Lengkap tentang Penganggaran, Pengalokasian, Penyaluran, Pelaporan, hingga Pemantauan dan Evaluasi Dana Desa. Visi Media 